\title{
Uncommon Birds at Spirit Lake
}

\section{By WILLIAM ANAKA}

On July 2nd, while investigating a Common Tern nesting colony on a neighbor's field, I had the pleasure of identifying two Black-bellied Plovers. One bird was unmistakeable in the black and white of its full spring plumage. The second one was apparently moulting, be ing dressed mostly in the duller, greyish autumn plumage, but with a very noticeable black belly. I had ample opportunity to observe both as they ran about on the mud flats, and later in flight as they circled about several times before again alighting.

Although noted fairly regularly in spring migration, this is my first summer record. A late spring date for May 30th this year gives rise to the possibility that they may be the same individuals who did not, for some reason, reach their usual summer territory in the Arctic.

The area where I saw the Blackbellied Plover proved to be an excellent spot for many species of shore birds. Originally a cultivated field alongside a shallow creek, it had flooded badly this spring and was left unworked. Shallow sloughs and potholes covered most of the area, creating long stretches of shoreline. The higher ridges were overgrown with weeds of all kinds, providing abundant cover for nests and young birds.

About seventy adult Common Terns were flying about overhead. I was able to locate a nest with two eggs, also three downy young, hiding under dense weeds. On a later visit, July 21st, many immature Common Terns were noted in flight so that most of the adults nested there but the dense growth and protective coloring of the eggs and young made it very difficult to locate either.

Another uncommon shore bird noted there was the Piping Plover. Five or six were seen running about, the pale sand color of their backs contrasting sharply with the dark muddy shore. On my second visit I saw two half-sized young running about with an adult, indicating that iney had nested there.
Many other species of bird life were present: Kildeers, Willets, Marbled Godwits and Wilson's Phalaropes, all protesting my intrusion. A small flock of Greater and Lesser Yellow-legs were noted. A large flock of ducks, mostly Lesser Scaup and Canvasbacks flew off at my arrival. About one hundred Ring-billed Gulls favored a mud bar as a resting place.

Another interesting bird noted this summer was the Hermit Thrushin a heavily wooded area in the sand hills along the south side of Spirit Lake. First attracted by its lovely song, I heard them on July 4th Unable to spend any time searching for it I left, returning several days later. Upon approaching the place where I'd heard the song, I heard an unfamiliar scolding note nearby. After several moments I spotted the bird on a low branch. With the aid of my binoculars I could see quite distinctly the reddish tail, contrasting with the olive-brown back. The habit of occasionally cocking its tail further aided the identification. On several later visits I have always been able to find the bird within a few yards of where I heard it sing. No doubt it was nesting there but I did not have time to thoroughly search the area.

\section{JUBILEE DRIVE}

(Cont. from Page 6)

No. 1 the evening is fragrant with hay and sweet clover and ripening grain. The tawny fields seem to give off light in the purple dusk. "A charm from the skies" rests on St. Joseph's colony, tidy and peaceful in its berth a field or two off the highway.

It is along No. 1 that we note the very latest angle in 50 years of progress - urban folk wealthy enough to move to the country, to make room for the farmers who have become wealthy enough to move to the city! 